ISSN 1392-3196 / e-ISSN 2335-8947

Zemdirbyste-Agriculture, vol. 100, No. 3 (2013), p. 311-316

DOI $10.13080 /$ z-a.2013.100.040

\title{
An analysis of spatial similarity in the variability of yields of winter wheat (Triticum aestivum $\mathbf{L}$.) cultivars in Western Poland
}

\author{
Henryk BUJAK ${ }^{1}$, Gwidon TRATWAL ${ }^{2}$, Ryszard WEBER ${ }^{3}$, Jan KACZMAREK ${ }^{1}$, \\ Edward GACEK ${ }^{2}$ \\ ${ }^{1}$ Wrocław University of Environmental and Life Sciences \\ Plac Grunwaldzki 24A, 53-363 Wrocław, Poland \\ E-mail: henryk.bujak@up.wroc.pl \\ ${ }^{2}$ Research Centre for Cultivar Testing \\ 63-022 Słupia Wielka, Poland \\ ${ }^{3}$ Institute of Soil Science and Plant Cultivation, State Research Institute \\ Orzechowa 61, 50-540 Wrocław, Poland
}

\begin{abstract}
The study makes use of yields of winter wheat (Triticum aestivum L.) cultivars obtained in a series of PostRegistration Variety Testing System, experiments conducted in 2006-2008 at 12 locations of diverse edaphic and climatic conditions of Western Poland. The experiments were carried out at two intensity levels in two replications. The paper presents an analysis pertaining to the intensive level of cultivation, which differed from the standard cultivation in nitrogen fertilization higher by $40 \mathrm{~kg} \mathrm{ha}^{-1}$, full chemical protection against fungal diseases, application of growth regulator and in foliar spray of the plants with multi-nutrient preparation. The experiments were set out in a split-block design. The trials involved the following 23 cultivars of winter wheat: 'Bogatka', 'Dorota', 'Finezja', 'Flair', 'Fregata', 'Kobiera', 'Kris', 'Legenda', 'Mewa', 'Muza', 'Nadobna', 'Nutka', 'Rapsodia', 'Rywalka', 'Sakwa', 'Sukces', 'Smuga', 'Tonacja', 'Trend', 'Turnia', 'Wydma', 'Zawisza', 'Zyta'. The statistical study started with an analysis of the original matrix of correlation between 12 experimental sites, consisting in formation of cores composed of pairs of locations described by the highest correlation coefficients. Next, factor analysis was performed, the aim of which was to diminish the dimensions of the correlation matrix. Based on the Kaiser criterion and the Cattell scree test, factors were selected whose Eigen values exceeded 1 . The analysis of the primary correlation matrix and the designated cores for pairs of locations indicate existence of three large subregions: a southern, northern and seaside subregion, as well as of four microregions around Nowa Wieś Ujska, Wyczechy, Krościna Mała and Masłowice. Geographically, the subregions stretch from the south-west in the northeastward direction. The factor analysis has allowed us to divide Western Poland into three subregions: southern, northern and the microregion of Nowa Wieś Ujska, differing with respect to the variability and ranking of yields of the winter wheat cultivars. It has been suggested that when choosing a cultivar, the farmer should take into account both the list of varieties recommended for a given area and their performance at the experimental station within the pertinent subregion, a site which is characterized by soil and climatic conditions similar to those prevailing at the target area. The soil type proved to be the environmental factor of paramount importance in determining winter wheat yields.
\end{abstract}

Key words: factor analysis, spatial similarity, Triticum aestivum, variability of yields.

\section{Introduction}

Cultivars of the winter wheat (Triticum aestivum L.) respond to several environmental factors, the most distinctly to climatic aspects, soil agricultural value and the level of agricultural intensification depending on the means and methods employed by man. Considering climatic variability of the country as well as differences in yields of cereal species and their sowing time, Dzieżyc (1993) has divided Poland into seven regions characterized by specific natural and agricultural conditions. Research Centre for Cultivar Testing (COBORU), Słupia Wielka, Poland has accepted this division for post-registration variety testing experiments to record the response of plants to the local conditions regionally.

Winter wheat cultivars respond spatially to diversified climatic factors such as precipitation, temperature, light, air humidity and specific reciprocal relationships of these elements, which can be conducive to the incidence of certain diseases and winter-hardiness. Cultivars also react in a variety of ways to the factors occurring in the microregion. These determinants include the agricultural value of soils and intensity level of crop management. These factors are widely variable even within small areas. Taking into account macro- and microregionation during recommendation of cultivars 
reduces the risk of substantial yield losses. To demonstrate how particular cultivars respond to environmental factors, it is necessary to conduct experiments with numerous sets of cultivars in a large number of locations and several years. Among the cultivars recommended for cultivation, there should be genotypes best adapted to the particular target region, which is characterized by marked stability in dynamic sense, but also cultivars narrowly adapted to a given environment and displaying high repeatability of yields in different years (Kaczyński, 1999; Jankowski et al., 2006; Navabi et al., 2006; Iwańska et al., 2008; Drzazga et al., 2009).

The Post-Registration Variety Testing System, introduced in 1998 covers experiments in all naturalagricultural regions, but organizationally it has been confined within administrative borders of particular voivodeships, where the outcome of investigations is analyzed and lists of recommended cultivars compiled. The lists of cultivars to be recommended are based on mean yields for a voivodeship, thus corresponding with macroregionalization. Demarcation of areas smaller than a whole voivodeship is more of microregionation nature. To delineate subregions for growing the winter wheat, it is necessary to assess the similarity of experimental sites with respect to the variability of yields of cultivars under analysis (Weber et al., 2011).

The objective of the present research was to distinguish subregions in Western Poland based on the similarity in the variability of cultivars yields in postregistration trials carried out at experimental stations located within different natural-agricultural regions.

\section{Material and methods}

The study makes use of yields of winter wheat (Triticum aestivum L.) cultivars obtained in a series of experiments conducted in 2006-2008 at 12 locations of diverse edaphic and climatic conditions of Western Poland (Fig. 1). The experiments were carried out at two intensity levels in two replications. At the standard level nitrogen fertilization was about $90 \mathrm{~kg} \mathrm{ha}^{-1}$, depending on nitrogen content in the soil. The paper presents an analysis pertaining to the intensive level of cultivation, which differed from the standard cultivation in nitrogen fertilization higher by $40 \mathrm{~kg} \mathrm{ha}^{-1}$, full chemical protection against diseases caused by fungi, application of growth regulator and in foliar spray of the plants with multi-nutrient preparation. The experiments were set out in split-block design. The size of plot was $15 \mathrm{~m}^{2}$. The trials involved the following 23 cultivars of winter wheat: 'Bogatka', 'Dorota', 'Finezja', 'Flair', 'Fregata', 'Kobiera', 'Kris', 'Legenda', 'Mewa', 'Muza', 'Nadobna', 'Nutka', 'Rapsodia', 'Rywalka', 'Sakwa', 'Sukces', 'Smuga', 'Tonacja', 'Trend', 'Turnia', 'Wydma', 'Zawisza', 'Zyta'.

The statistical study started with an analysis of the original matrix of correlation between 12 experimental sites, consisting in formation of cores composed of pairs of locations described by the highest correlation coefficients. An assumption was made that of practical significance are those correlation coefficients $r$ whose determination coefficients $r^{2}$ exceed 0.5 , as such pairs are characterized by substantial similarity in the variability of cultivars' yields. Further, factor analysis was performed (Stevens, 1986), whose aim was to diminish the dimensions of the correlation matrix. By this statistical method, hidden structures between the studied variables were being sought, the ones that are difficult to define on the basis of the original data in the matrix.

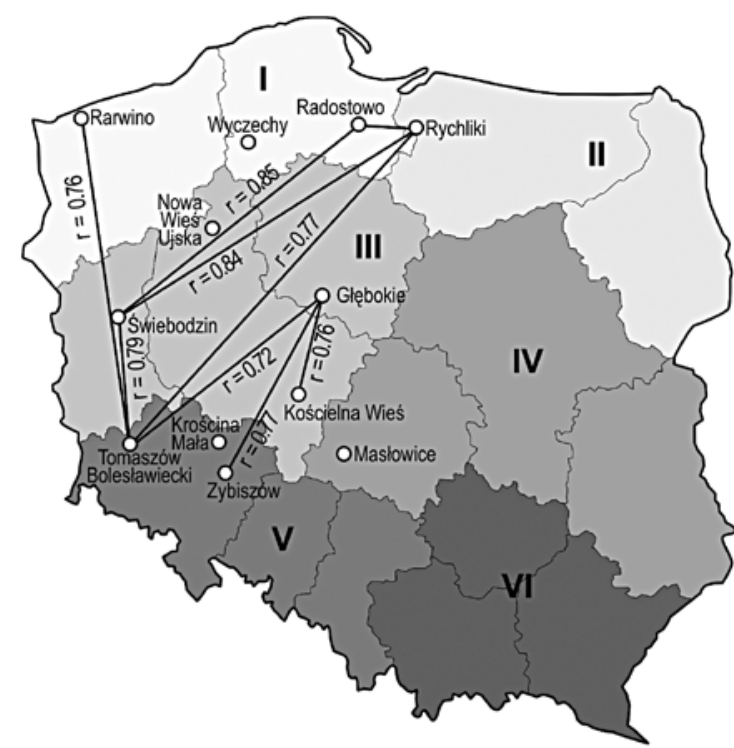

Figure 1. Distribution of experimental sites in naturalagricultural regions and cores of the correlation coefficients

The factors acquired with this statistical method defined the relationships between the groups of the previously analyzed variables. If two variables under investigations exhibited significant correlation with the same factor, then the essential section of the correlation between the studied variables would be accounted for by a common factor distinguished. The main purpose of this research was to arrive at a division of the original number of variables, i.e. experimental sites, into factors within which the cultivars would not differ with regard to variability of yields. With the application of the Bartlett (1950) test, the analyzed correlation matrix was found not to represent an entity matrix. The high value of the coefficient justified the use of factor analysis. The decision concerning the number of factors was taken based on the Eigen values of the magnitude of variance of a given factor on the assumption that the magnitude of initial variance (after standardization) equalled 1.

Based on the Kaiser (1960) criterion and the Cattell (1966) scree test, factors were selected whose Eigen values exceeded 1 . The variance of each factor defines what proportion of total variability of all primary variables (sites) is accounted for by a given factor. Next, resources of common variability, defined by a given number of factors, were analyzed. Thanks to reduction of the correlation matrix factor matrix was obtained, and then factor loadings were calculated with and without the Varimax rotation between the primary variables and factors.

\section{Results}

The soil quality class, yearly amount of precipitation in total, mean yearly temperatures and yields of the winter wheat are presented in Table 1 . The highest yields were obtained on good soils (black soils, brown soils developed on light clay, pseudopodzolic - light clays on silt) at the locations of Radostowo, Rychliki, Zybiszów and Krościna Mała. Substantially lower yield values were recorded for poorer soils (pseudopodzols developed on light dusty clay on loose sand, podzolic soils originated from regular dust on loose sand, podzolic soils produced by light clayish sand) at Tomaszów Bolesławiecki, Masłowice and Nowa Wieś Ujska. 
Table 1. Soil type, precipitation, temperature and yields at experimental locations

\begin{tabular}{lcccccc}
\hline \multicolumn{1}{c}{ Location } & $\begin{array}{c}\text { Region } \\
\text { of Poland }\end{array}$ & $\mathrm{pH}$ & Soil type & $\begin{array}{c}\text { Yearly amount } \\
\text { of precipitation } \\
\text { mm }\end{array}$ & $\begin{array}{c}\text { Mean yearly } \\
\text { temperature } \\
{ }^{\circ} \mathrm{C}\end{array}$ & $\begin{array}{c}\text { Yield } \\
\text { tha }^{-1}\end{array}$ \\
\hline Rarwino (Rar) & I & 7.2 & 5Bw pgl:gl & 661 & 5.8 & 7.4 \\
Wyczechy (Wy) & I & 5.9 & 4Bw pgl:gl & 600 & 5.1 & 7.3 \\
Radostowo (Rad) & I & 6.9 & 1Dz płi & 471 & 5.1 & 9.4 \\
Rychliki (Ry) & II & 5.7 & 2Bw gl & 532 & 5.3 & 9.8 \\
Nowa Wieś Ujska (Nw) & III & 5.5 & 4A pgl:gl & 459 & 5.5 & 6.4 \\
Glębokie (Gl) & III & 6.8 & 2D glp & 416 & 5.4 & 6.9 \\
Świebodzin (Sw) & III & 5.9 & Bw pgm:gp & 491 & 6.1 & 8.5 \\
Kościelna Wieś (Kw) & III & 6.2 & 2Bw plz:gs & 355 & 6.1 & 8.1 \\
Masłowice (Ma) & IV & 6.5 & 4 A płz:pl & 426 & 5.6 & 6.8 \\
Krościna Mała (Km) & V & 6.6 & 2A gl:i & 446 & 6.2 & 9.7 \\
Tomaszów Bolesławiecki (Tb) & V & 6.1 & 5A glp:pl & 506 & 5.6 & 5.9 \\
Zybiszów (Zy) & V & 6.3 & 2Dz gsp:ps & 481 & 6.0 & 9.2 \\
\hline
\end{tabular}

Notes. Denotations (FAO-WRB 2006-2007): 5Bw pgl:gl - Dystric Cambisol (CMd) developed on loamy sand on medium-deep sandy loam, 4Bw pgl:gl - Dystric Cambisol developed on loamy sand on loam, 1Dz płi - Phaeozem (PH) developed on silty clay, 2Bw gl - Dystric Cambisol developed on loam, 4A pgl:gl - Podzol (PZ) developed on loamy sand on medium-deep loam, 2D glp - Chernozem $(\mathrm{CH})$ developed on loam, Bw pgm:gp - Dystric Cambisol developed on loamy sand on sandy loam, 2Bw płz:gs - Eutric Cambisol (CMe) developed on silty loam on loam, 4A płz:pl - Luvisol (LV) developed on silt on sand, 2A gl:i - Luvisol developed on loam on clay, 5A glp:pl - Luvisol developed on silty loam on medium-deep sand, 2Dz gsp:ps - Phaeozem developed on silty loam on medium-deep loamy sand.

Figure 2 presents the regression straight line for the yields and sum of precipitation. No correlation has been found between the yields and the total precipitation. The slope of the regression straight line and the wide dispersal of points around this line indicate insignificant correlation between the yields and precipitation overall. The equation of the regression line is: $y=81.7-0.0045 x$.

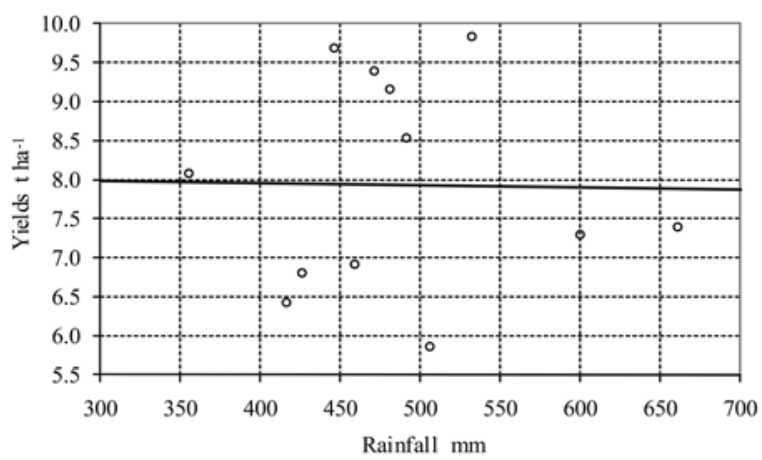

Figure 2. Dependence of the winter wheat yield on the total precipitation during a growing season

Also, no significant correlation has been found between the mean yearly temperature and the level of yields $(y=38.17+7.31 x)$ (Fig. 3). This is evidenced by the slope of the regression line as well as by the wide dispersal of points representing the winter wheat yields (Fig. 3).

Table 2 illustrates the original correlation matrix containing 12 variables that characterize performance of 23 cultivars. Based on this correlation matrix, one can compile pairs of experimental locations that are distinguishable by comparable variability of yields, for which the coefficient of determination $R^{2}$ exceeded the value of 0.5 . The highest correlation coefficients $(r=0.85)$ characterized the pairs of variables composed of the locations of Świebodzin and Radostowo, and that of Świebodzin and Rychliki $(r=0.84)$. They made up two cores of the first group. The correlation coefficient between Radostowo and Rychliki was also high $(r=0.79)$. High correlation coefficients were also observed in the case of the location pairs: Tomaszów Bolesławiecki and Rychliki $(r=0.77)$, and Tomaszów Bolesławiecki and Świebodzin

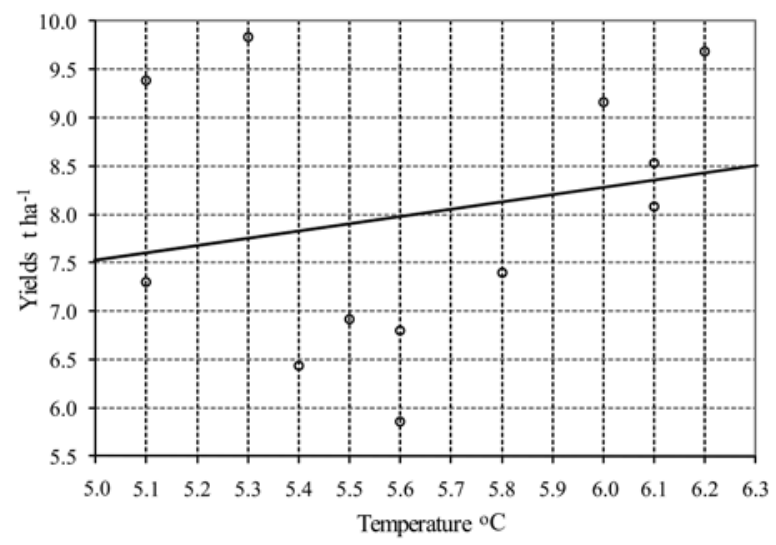

Figure 3. Dependence of the winter wheat yield on the mean temperature during a growing season

$(r=0.79)$. These four sites represented the northern subregion. Within this subregion, two microregions were distinguished, i.e. of Nowa Wieś Ujska and Wyczechy. These two microregions were not correlated with any other location. Searching for the next highest correlation coefficients, cores that linked Głębokie with Kościelna Wieś $(r=0.76)$, with Zybiszów $(r=0.77)$ and with Tomaszów Bolesławiecki $(r=0.72)$, were created. These four locations represent the southern subregion. Inside the southern subregion, two microregions were demarcated - around Krościna Mała and Masłowice. At these experimental sites the determination coefficient calculated as related to the remaining locations did not exceed the value 0.5 . There has been delineated one more core - for the pair composed of Rarwino and Tomaszów Bolesławiecki. The similarity of variability of yields at these sites resulted probably from the experiments being situated on the poorest soils ( $5 \mathrm{~A}$ and $5 \mathrm{~B})$. Rarwino represents a seaside region of poorer soils and therefore no relationship was observed with Radostowo or Rychliki, situated in the Vistula River Marshland on good soils (degraded black soils, brown soils made from light clays). A comparison of yields at experimental stations shows that the edaphic conditions played a critical role in shaping the level of yields. 
Table 2. Matrix of correlation between of cultivar yields at experimental stations

\begin{tabular}{cccccccccccccccc}
\hline Location & Kw & Rad & Rar & Wy & Nw & Gl & Sw & Ry & Ma & Km & Tb \\
\hline Kw & 1.00 & 0.42 & 0.62 & 0.00 & 0.26 & 0.76 & 0.65 & 0.61 & 0.64 & 0.53 & 0.76 & 0.72 \\
Rad & 0.42 & 1.00 & 0.55 & 0.59 & 0.13 & 0.46 & 0.85 & 0.79 & 0.02 & 0.05 & 0.67 & 0.17 \\
Rar & 0.62 & 0.55 & 1.00 & 0.25 & 0.24 & 0.71 & 0.64 & 0.65 & 0.43 & 0.26 & 0.69 & 0.55 \\
Wy & 0.00 & 0.59 & 0.25 & 1.00 & 0.25 & 0.008 & 0.47 & 0.41 & -0.22 & -0.24 & 0.25 & -0.28 \\
Nw & 0.26 & 0.13 & 0.24 & 0.25 & 1.00 & 0.24 & 0.19 & 0.16 & 0.23 & 0.17 & 0.22 & 0.12 \\
Gl & 0.76 & 0.46 & 0.71 & 0.08 & 0.24 & 1.00 & 0.66 & 0.66 & 0.66 & 0.49 & 0.72 & 0.77 \\
Sw & 0.65 & 0.85 & 0.64 & 0.47 & 0.19 & 0.66 & 1.00 & 0.84 & 0.30 & 0.26 & 0.79 & 0.40 \\
Ry & 0.61 & 0.79 & 0.65 & 0.41 & 0.16 & 0.66 & 0.84 & 1.00 & 0.31 & 0.23 & 0.77 & 0.45 \\
Ma & 0.64 & 0.02 & 0.43 & -0.22 & 0.23 & 0.66 & 0.30 & 0.31 & 1.00 & 0.58 & 0.47 & 0.69 \\
Km & 0.53 & 0.05 & 0.26 & -0.24 & 0.17 & 0.49 & 0.26 & 0.23 & 0.58 & 1.00 & 0.42 & 0.60 \\
Tb & 0.76 & 0.67 & 0.69 & 0.25 & 0.22 & 0.72 & 0.79 & 0.77 & 0.47 & 0.42 & 1.00 & 0.61 \\
Zy & 0.72 & 0.17 & 0.55 & -0.28 & 012 & 0.77 & 0.40 & 0.45 & 0.69 & 0.60 & 0.61 & 1.00 \\
\hline
\end{tabular}

Explanations of abbreviations in Table 1

The cores marked in Figure 1 produce a network of connections between the locations, which designate at least three overlapping subregions and four microregions.

In the original correlation matrix - in spite of taking into account practically important relationship between the experimental sites under analysis - it is difficult to ascertain maximum similarity or the highest differences between the studied experimental locations, as it is impossible to establish the hidden relationships underlying the division into groups. So, primary correlation matrix was acknowledged as a partial solution to the problem of how to spatially group the experimental sites. More information could be obtained through the application of factor analysis. And thus, the data on the variability of cultivar yields at the experimental locations were treated as original variables and an attempt was made to reduce them by the method of factor analysis. The aim of that analysis was also to define the contribution of particular experimental sites to the overall variability. The first step of the factor analysis undertaken was transformation of 12 correlated variables (locations) into " $n$ " uncorrelated factors. The decision as to the number of factors was taken on the basis of an analysis of Eigen values (Table 3 ) - the magnitude of variance of a given factor at the assumption that the magnitude of initial variance (after standardization) equals 1. Application of the Kaiser criterion enabled us to extract three principal components whose Eigen values exceeded 1 . Those factors accounted for $80.3 \%$ of the total variability of yields. The variance of each factor determined certain magnitude of variability in the original values which was represented by its Eigen value. Consequently, Eigen values reflected the magnitude of common variance distinguished through a given number of factors.

Further, communalities, interpreted through three defined factors, were analyzed (Table 4). The communality of a given variable (location) represented that part of variance which can be attributed to common factors. The second column of this table shows the share of the variance of a given variable distinguished by the second factor, whereas the third column of this compilation illustrates the contribution of the variance of a studied variable determined by the first two principal

Table 3. Eigen values - extraction: principal components

\begin{tabular}{|c|c|c|c|c|}
\hline & & Percentage & & \\
\hline Value & $\begin{array}{l}\text { Eigen } \\
\text { value }\end{array}$ & $\begin{array}{c}\text { of the } \\
\text { overall } \\
\text { variance }\end{array}$ & $\begin{array}{l}\text { Accumulated } \\
\text { Eigen value }\end{array}$ & $\begin{array}{c}\text { Accumulated } \\
\text { percentage }\end{array}$ \\
\hline First factor & 6.21 & 51.71 & 6.21 & 51.72 \\
\hline Second factor & 2.41 & 20.11 & 8.62 & 71.83 \\
\hline Third factor & 1.01 & 8.45 & 9.63 & 80.29 \\
\hline
\end{tabular}

Table 4. Communalities (unrotated)

\begin{tabular}{lcccc}
\hline \multicolumn{1}{c}{ Variable } & $\begin{array}{c}\text { First } \\
\text { factor }\end{array}$ & $\begin{array}{c}\text { Second } \\
\text { factor }\end{array}$ & $\begin{array}{c}\text { Third } \\
\text { factor }\end{array}$ & $\begin{array}{c}\text { Communalities } \\
R^{2}\end{array}$ \\
\hline Kościelna Wieś & 0.74 & 0.79 & 0.79 & 0.75 \\
Radostowo & 0.46 & 0.87 & 0.89 & 0.85 \\
Rarwino & 0.65 & 0.66 & 0.65 & 0.61 \\
Wyczechy & 0.06 & 0.73 & 0.66 & 0.59 \\
Nowa Wieś Ujska & 0.09 & 0.09 & 0.80 & 0.20 \\
Głębokie & 0.78 & 0.82 & 0.95 & 0.80 \\
Świebodzin & 0.72 & 0.87 & 0.82 & 0.86 \\
Rychliki & 0.70 & 0.82 & 0.88 & 0.78 \\
Masłowice & 0.38 & 0.74 & 0.84 & 0.68 \\
Krościna Mała & 0.27 & 0.59 & 0.75 & 0.46 \\
Tomaszów & 0.81 & 0.82 & 0.59 & 0.78 \\
Bolesławiecki & 0.54 & 0.82 & 0.83 & 0.78 \\
Zybiszów & & & &
\end{tabular}

components. The last column includes the multiple correlation coefficient $R^{2} X U$ between the primary variable $X_{i}$ and new variables (factors). This proportion of variance of a given index (location), which results from common factors bears the name of communality, which is resources of common variability. Based on Table 4, one can state that $86 \%$ of variability of yields at the location of Świebodzin, $85 \%$ at Radostowo and $80 \%$ at Głębokie is accounted for by the remaining experimental sites, while the variability of yields at Nowa Wieś Ujska (20\%), Krościna Mała (46\%), Wyczechy (59\%) and Rarwino $(61 \%)$ is the least conditioned by the variability of yields at the other environments. Most of the locations are, to a great extent, defined through the rest of variables comprised within the model. Coefficient of determination $R^{2}$ indicates the adequacy of the model's adjustment to the variables studied. Communalities can be applied in the estimation of usefulness of factor analysis. Values approaching zero indicate that this particular variable does not fit into the accepted model.

Dissolution of the correlation matrix into factors allowed us to acquire a factor matrix of each variable with each factor (Table 5). Factor loadings are equivalent to correlation coefficients between given variables and particular factors. Table 5 shows the values of rotated factor loadings obtained by the Varimax method. Rotation enabled to obtain such configuration of loadings at each factor which illustrates the possibly highest diversification, thus rendering the interpretation of the results easy. On the basis of this table, one can conclude that the locations of Radostowo, Świebodzin, Rychliki and Tomaszów Bolesławiecki are highly correlated with the first factor (northern subregion). The second factor, on the other hand, exhibits significant links with 
Table 5. Factor loadings (Varimax normalized); extraction: principal components

\begin{tabular}{lccc}
\hline \multicolumn{1}{c}{ Variable } & $\begin{array}{c}\text { First } \\
\text { factor }\end{array}$ & $\begin{array}{c}\text { Second } \\
\text { factor }\end{array}$ & $\begin{array}{c}\text { Third } \\
\text { factor }\end{array}$ \\
\hline Kościelna Wieś & 0.47 & $0.74^{*}$ & 0.12 \\
Radostowo & $0.94^{*}$ & -0.02 & 0.02 \\
Rarwino & 0.65 & 0.46 & 0.14 \\
Wyczechy & 0.67 & -0.46 & 0.36 \\
Nowa Wieś Ujska & 0.08 & 0.13 & $0.96^{*}$ \\
Głębokie & 0.52 & $0.73^{*}$ & 0.12 \\
Świebodzin & $0.89^{*}$ & 0.28 & 0.07 \\
Rychliki & $0.86^{*}$ & 0.31 & 0.02 \\
Maslowice & 0.03 & $0.85^{*}$ & 0.18 \\
Krościna Mała & -0.01 & $0.76^{*}$ & 0.11 \\
Tomaszów Bolesławiecki & $0.73^{*}$ & 0.54 & 0.08 \\
Zybiszów & 0.21 & $0.89^{*}$ & 0.04 \\
\hline \multicolumn{1}{c}{ Explained variance } & 4.38 & 4.09 & 1.16 \\
\multicolumn{1}{c}{ Participation } & 0.36 & 0.34 & 0.10 \\
\hline
\end{tabular}

* - significance at 0.05 level

the locations at Kościelna Wieś, Głębokie, Masłowice, Krościna Mała and Zybiszów (southern subregion).

The third factor is highly correlated with the location of Nowa Wieś Ujska (microregion). The last line of the table shows the participation of each of the factors in the overall communality. The first factor explains 36\% of the total variability of cultivar yields, the second factor accounts for $34 \%$ of this variability. The third factor is connected with communalities only in $10 \%$.

\section{Discussion}

Studies of the genotype-environment interaction are focused on the evaluation of cultivars in respect of yield stability and on their division into groups on the basis of narrow or wide adaptation (Samonte et al., 2005; Navabi et al., 2006; Gauch et al., 2008; Rodriguez et al., 2008; Roozeboom et al., 2008). Among the cultivars recommended for growing, also those genotypes are often regarded as desirable which are narrowly adapted to a defined environment and which display high repeatability of yields in years (Jankowski et al., 2006; Drzazga et al., 2009). The choice of location for an experimental station should ensure that it is representative of the whole region considering diverse edaphic-climatic conditions. Not all locations will be representative of the entire region to the same extent. Some of them can better characterize a small area, the so-called subregion, or even a smaller area, which is called microregion. An analysis of the correlation matrix and of designation of cores for pairs of locations enabled us to delineate a southern and northern subregion as well as four microregions around the locations Nowa Wieś Ujska, Wyczechy, Krościna Mała and Masłowice. The performed factor analysis distinguished four locations subregions - differing in the variability of yields. The first subregion comprised Radostowo, Świebodzin, Rychliki and Tomaszów Bolesławiecki (northern subregion). Kościelna Wieś, Głębokie, Masłowice, Krościna Mała and Zybiszów composed the second (southern) subregion, whereas the experimental station at Nowa Wieś Ujska constituted a third uni-element subregion (microregion) distinguishable by a distinct ranking of yields as compared with the remaining subregions. The low factor loadings at Rarwino and Wyczechy point out that this two can make a fourth subregion but different yield ranking at these stations does not confirm such a suggestion. Rarwino is the only experimental site representing the seashore subregion of poor soils. A comparison of correlation coefficient for particular sites allows a statement that the station at Nowa Wieś Ujska is distinguishable by low relationship with the remaining experimental sites. Such a finding is confirmed by the low value of communality recorded for this experimental station. One can thus presume that the area assigned to the station at Nowa Wieś Ujska constitutes a microregion of different soil and climatic conditions as compared with the rest of the experimental sites, which are highly correlated with either the second or the third factor. The experimental stations at Rarwino and Wyczechy, insignificantly correlated with the first factor, were characterized by a higher total amount of rainfall in comparison with the other experimental sites, whereas the experimental locations of Kościelna Wieś, Głębokie, Masłowice, Krościna Mała and Zybiszów were distinguished by a lower precipitation overall as compared with the other sites. In numerous papers the authors emphasize that the total amount of precipitation and average temperatures during vegetation are factors which determine winter wheat yields (Weikai, Hunt, 2001; Brancourt-Hulmel, Lecomte, 2003). In this study the ranking of cultivars' yields was in the main dependent only on the specific interaction of the genotypes with the edaphic conditions at particular locations where the post-registration experiments were being conducted. In other studies the environmental conditions prevailing at the site after wheat flowering exert more influence on yield variability than the environmental factors at the initial stages of the plants' development (Reynolds et al., 2002). Certain cultivars produce high yields in spite of substantial water shortage during the period (Ahmad et al., 2003).

\section{Conclusions}

1. The analysis of the primary correlation matrix and the designated cores for pairs of locations indicate the existence of three large subregions: a southern, northern and seaside subregion, as well as four microregions around Nowa Wieś Ujska, Wyczechy, Krościna Mała and Masłowice. Geographically, the subregions mentioned stretch from the south-west in the north-eastward direction.

2 . The factor analysis has allowed us to divide Western Poland into three subregions: southern, northern and the microregion of Nowa Wieś Ujska, different with respect to the variability and ranking of yields of the winter wheat (Triticum aestivum L.) cultivars

3. While choosing a cultivar, one should take into account both the list of varieties recommended for a given area and their performance at the experimental station within the pertinent subregion, a site which is characterized by soil and climatic conditions similar to those prevailing at the target area.

4. The soil type proved to be the environmental factor of paramount importance in determining winter wheat yields.

Received 06122012

Accepted 24042013

\section{References}

Ahmad R., Nadir S., Ahmad N., Hussain K. 2003.Yield potential and stability of nine wheat varieties under utter stress conditions. International Journal of Agriculture and Biology, 5 (1): 7-9

Bartlett L. L. 1950. Tests of significance in factor analysis. British Journal of Psychology, Statistical Section, 3: 77-85

Brancourt-Hulmel M., Lecomte C. 2003. Effect of environmental varieties on genotype $\times$ environment interaction of winter wheat. Crop Science, 43: 608-617 
Cattell R. B. 1966. The scree test for the number of factors. Multivariate Behavioral Research, 1: 245-276 http://dx.doi.org/10.1207/s15327906mbr0102 10

Drzazga T., Paderewski J., Mądry W., Krajewski P. 2009. The estimation of winter wheat field response to variable environmental conditions in post-registration cultivar tests. Biuletyn Instytutu Hodowli i Aklimatyzacji Roślin, 253: 71-82 (in Polish)

Dzieżyc J. 1993. Yield-determinant factors - plant cropping. Warszawa-Wrocław, Poland (in Polish)

Gauch H. G., Piepho H. P., Annicchiarico P. 2008. Statistical analysis of yield trials by AMMI and GGE: Further considerations. Crop Science. 48: 866-889 http://dx.doi.org/10.2135/cropsci2007.09.0513

Iwańska M., Mądry W., Drzazga T., Rajfura A. 2008. Assessment of wide adaptation degree of winter wheat cultivars by same statistical measures using yield data from preregistration trials. Biuletyn Instytutu Hodowli i Aklimatyzacji Roślin, 250: 67-86 (in Polish)

Jankowski P., Zieliński A., Mądry W. 2006. Analysis of genotype-environment interaction for winter wheat using graphical GGE biplot method. Part I. The method. Biuletyn Instytutu Hodowli i Aklimatyzacji Roślin, 240/241: 51-60 (in Polish)

Kaczyński L. 1999. Response of crop plants to environmental factors. Basics of organization and design of experiments with registered cultivars in Lower Silesia. Edition of the Centralny Ośrodek Badania Odmian Roslin Uprawnych Słupia Wielka: 31-46 (in Polish)

Kaiser H.F. 1960. The application of electronic computers to factor analysis. Educational and Psychological Measurement. 20: 141-151 http://dx.doi.org/10.1177/001316446002000116
Navabi A., Yang R. C., Helm J., Spaner D. M. 2006. Can spring wheat-growing mega-environments in the Northern Great Plants be dissected for representative locations or nicheadapted genotypes? Crop Science. 46: 1107-1116 http://dx.doi.org/10.2135/cropsci2005.06-0159

Reynols M. P., Trethowan R., Crossa J., Vargas M., Sayre K. D. 2002. Physiological factors associated with genotype by environment interaction in wheat. Field Crops Research, 75 (2-3): 139-160 http://dx.doi.org/10.1016/S0378-4290(02)00023-0

Rodriguez M., Rau D., Papa R., Attene G. 2008. Genotype by environment interactions in barley (Hordeum vulgare L.) different responses of landraces, recombinant inbred lines and varieties to Mediterranean environment. Euphytica. 163: 231-247 http://dx.doi.org/10.1007/s10681-007-9635-8

Roozeboom K. L., Schapaugh W. T., Tuinstra M. R., Vanderlip R. L., Milliken G. A. 2008. Testing wheat in variable environments: genotype environment, interaction effects, and grouning test locations. Crop Science. 48: 317-330 http://dx.doi.org/10.2135/cropsci2007.04.0209

Samonte S. O., Wilson L. T., McClung A. M., Medley J. C. 2005. Targeting cultivars onto rice growing environments using AMMI and SREG GGE biplot analyses. Crop Science. 45: 2414-2424 http://dx.doi.org/10.2135/cropsci2004.0627

Stevens J. 1986. Applied multivariate statistics for the social sciences. Lawrence Erlbaum Associates, Hillsdale, USA

Weber R., Bujak H., Kaczmarek J., Gacek E. 2011. Analysis of yield variability in winter wheat cultivars in South-Western Poland. Biuletyn Instytutu Hodowli i Aklimatyzacji Roślin, 260/261: 121-134 (in Polish)

Weikai Y., Hunt L.A. 2001. Interpretation of genotype x environment interaction for winter wheat vield in Ontario. Crop Science, 41: 19-21 http://dx.doi.org/10.2135/cropsci2001.41119x

ISSN 1392-3196 / e-ISSN 2335-8947

Zemdirbyste-Agriculture, vol. 100, No. 3 (2013), p. 311-316

DOI $10.13080 /$ z-a.2013.100.040

\title{
Paprastojo žieminio kviečio (Triticum aestivum L.) veislių derliaus svyravimo erdvinio panašumo Vakarų Lenkijoje analizė
}

\author{
H. Bujak ${ }^{1}$, G. Tratwal ${ }^{2}$, R. Weber ${ }^{3}$, J. Kaczmarek ${ }^{1}$, E. Gacek ${ }^{2}$ \\ ${ }^{1}$ Vroclavo aplinkos ir gyvybès mokslų universitetas, Lenkija \\ ${ }^{2}$ Veislių tyrimų centras, Lenkija \\ ${ }^{3}$ Valstybinis dirvožemio mokslo ir augalininkystès tyrimų institutas, Lenkija
}

\begin{abstract}
Santrauka
Analizuoti žieminio kviečio derliai, gauti veisliu poregistraciniu tyrimų metu, kurie buvo atlikti 2006-2008 m. 12-oje Vakarų Lenkijos vietovių, besiskiriančių dirvožemio ir klimato sąlygomis. Eksperimentai atlikti dviem intensyvumo lygiais ir dviem pakartojimais. Analizuotas intensyvus auginimas, kuris nuo standartinio skyrèsi 40 $\mathrm{kg} \mathrm{ha}^{-1}$ didesniu azoto tręšimo lygiu. Buvo naudota visapusiška cheminè apsauga nuo grybinių ligų, augalų augimo reguliatoriai ir žieminių kviečių tręšimas per lapus kompleksinėmis trąšomis. Eksperimentas atliktas skaidytụ laukelių metodu. Tirtos 23 žieminio kviečio veislès: 'Bogatka', 'Dorota', 'Finezja', 'Flair', 'Fregata', 'Kobiera', 'Kris', 'Legenda', 'Mewa', 'Muza', 'Nadobna', 'Nutka', 'Rapsodia', 'Rywalka', 'Sakwa', 'Sukces', 'Smuga', 'Tonacja', 'Trend', 'Turnia', 'Wydma', 'Zawisza', 'Zyta'. Statistinis vertinimas pradètas analizuojant pirminę koreliacijos matricą tarp 12-os tyrimo vietovių, formuojant pagrindines vietovių poras, pasižyminčias didžiausiais koreliacijos koeficientais. Po to atlikta faktorinė analizè, kurios tikslas - sumažinti koreliacijos matricos dydị. Remiantis Kaiser kriterijumi ir Cattell scree testu, buvo pasirinkti veiksniai, kurių Eigen vertès viršijo 1. Pirminés koreliacijos matricos analizè ir suformuotos pagrindinès vietovių poros išryškino trijų didelių subregionų: pietinio, šiaurinio bei pajūrio, taip pat ir keturių mikroregionų aplink Nowa Wieś Ujska, Wyczechy, Krościna Mała ir Masłowice egzistavimą. Geografiškai subregionai driekiasi nuo pietvakarių šiaurès rytų kryptimi. Faktorinès analizès duomenimis, Vakarų Lenkiją galima dalinti ị tris subregionus: pietinį, šiaurinị ir Nowa Wieś Ujska mikroregioną, besiskiriančius žieminio kviečio veislių derliaus svyravimais ir dyžiu. Nustatyta, kad rinkdamiesi veislę ūkininkai turètų atsižvelgti ir ị konkrečiai vietovei rekomenduojamų veislių sąrašą ir tyrimų rezultatus, gautus bandymų stotyse tuose regionuose, kurių sąlygos yra panašios į ūkininkų dirvožemio bei klimato sąlygas. Nustatyta, kad dirvožemio tipas yra labai svarbus aplinkos veiksnys, lemiantis žieminių kviečių derlių.
\end{abstract}

Reikšminiai žodžiai: derliaus svyravimai, faktorinè analizè, erdvinis panašumas, Triticum aestivum. 